\title{
The case for environmental advocacy
}

\section{Clara Changxin Fang ${ }^{1}$ (D)}

Accepted: 1 December 2020 / Published online: 6 January 2021

(C) AESS 2021

When lockdowns due to the coronavirus pandemic cleared the air pollution and brought down greenhouse gas emissions in many parts of the world, many environmentalists rejoiced. However, the effects were not nearly enough to change the trajectory of greenhouse gas emissions and it was also short lived. At the peak of the lockdown, in April 2020, emissions were down $17 \%$ globally from a year ago (Le Quéré et al. 2020). By early June, daily carbon-dioxide emissions were within 5\% of their 2019 levels, and by September, global emissions were nearly back to pre-pandemic levels. The forecast is that 2020 emissions will likely be between 4 and $7 \%$ lower than last year (World Meteorological Association 2020). To keep global warming within $1.5^{\circ} \mathrm{C}$, scientists tell us that emissions must drop by $7 \%$ a year on average (World Meteorological Association 2020).

The coronavirus pandemic provided an unmatched opportunity to witness how much widespread behavior change can help in the fight against climate change. The answer is not very much. Lockdowns drive down emissions when universally implemented, but they are not sustainable and cause widespread economic damage. Focusing on personal carbon footprints does nowhere near enough to curb global warming and is, in fact, a dangerous distraction from the collective advocacy we need to transform our culture, economy, and energy systems. The reason is that the vast majority of environmental impact is the result of industrial activities, and individual actions do not address the incentives and structures that created the problem. Here are a few examples.

Suppose you are an exceptional environmentalist and recycle and compost almost all of your waste. Then, you went to your university (or wherever you are employed) and convinced it to recycle and compost all of its waste too. All of that paper, plastic, and food scraps look like a lot, but it

Clara Changxin Fang

cfang@antioch.edu

1 Antioch University New England, 40 Avon St, Keene, NH 03431, USA accounts for only $3 \%$ of total waste in the USA (Jensen 2009; Frontier Group 2018).

Then, you go home where you take shorter showers. The average amount of water used by a shower is 2.5 gallons per minute, so by shortening your shower by 1 min every day, you save 912 gallons of water a year (U.S. EPA 2020). Not bad. However, fracking uses an average of 9.6 million gallons of water for each well (Magill 2020). This means you would have to shorten your shower every day for 10,536 years to save the same amount of water used to frack a single well. Fracking used nearly 250 billion gallons of water in the USA between 2005 and 2015 (Duke Today 2015) compared to 142 million gallons for public use in the same period (U.S. Geological Survey 2016).

You also have a 20-mile round trip commute each day, and you reduce emissions by upgrading your car from one that gets $20 \mathrm{mpg}$ to one that gets $30 \mathrm{mpg}$, saving $1600 \mathrm{lbs}$ of $\mathrm{CO}_{2}$ a year (Fat Knowledge 2006). However, if you took that commute by public transit, you would reduce your emissions by more than $4800 \mathrm{lbs}$ a year (American Public Transportation Association 2016). The bus carries other people too, so if your bus replaced the commutes of twenty people in single occupancy vehicles, then together you would avoid 96,000 lbs (44 t) of $\mathrm{CO}_{2}$. That is 58 times more $\mathrm{CO}_{2}$ avoided than upgrading your own car.

Additionally, you become a vegetarian, saving at least $3000 \mathrm{lbs}$ of $\mathrm{CO}_{2}$ per year compared to meat eaters (The Carbon Fund 2016). That is a big impact, probably the biggest you can make, other than giving up driving. Our collective eating habits impact the agricultural system, but even more profoundly, federal subsidies determine what gets produced and consumed in our agricultural system. Because corn, wheat, and soybean production are heavily subsidized, many farms that would have grown diverse crops for local consumption grow exclusively corn, wheat, and soybean. According to the US Department of Agriculture, corn acreage in the USA has increased from a government-mandated low of 60.2 million planted acres in 1983 to close to or exceeding 90 million since $2010,40 \%$ of which is used for ethanol and $30 \%$ of 
which is fed to livestock (U.S Department of Agriculture 2020).

You may argue that if everyone were like you-became vegetarian, drove less, and moved to smaller dwellings - the overall impact could be pretty significant. While residential energy use accounts for $16 \%$ of total energy use in the USA (U.S. Energy Information Administration 2019) and residential plus commercial water use accounts for $12 \%$ of freshwater use in the USA (U.S. Geological Survey 2016), it will take a lot of resources to conduct mass public education campaigns on sustainable living and many of them do not result in behavior change.

For example, $\$ 14$ billion was spent on the 2020 election to influence voter's ballot decisions (Center for Responsive Politics 2020). Voting is relatively simple (except in a pandemic during the 2020 US election). Hypothetically, it should take you no more than an hour to get to your polling place, stand in line, and cast your ballot, and you do not have to do it again for 2 years. Even then, only $60 \%$ of eligible voters voted in the 2016 election and 50\% voted in the 2018 election (United States Election Project 2020). An educational campaign to get people to eat less meat, live in smaller houses, or drive less would have to be mounted at the scale of a presidential campaign to get a fraction of that voting participation, and these consumer choices are far more difficult than voting.

In the end, no matter how many cans you recycle or how much you shorten your shower, our systems and institutions will continue to warm the planet and pollute the oceans without legislative mandates. Bill McKibben, author and founder of the worldwide 350 climate movement, writes:

We don't have time for incremental, individual changes. Time is just a physical constraint that we're dealing with. And so the most important things an individual can do is be less of an individual. Join together with other people in movements large enough to affect changes in policy and economics that might actually move the system enough to matter (Hagan 2019).

For the most part, instead of confronting the systems and institutions that have created the environmental crisis, we exhort individuals to take shorter showers and for employees to turn off the lights. I think there are several reasons for this timid environmentalism.

First, academics, often highly influential proponents of environmentalism, for the most part do not like being confrontational. Guided by an ideology that encourages objectivity, many scientists, scholars, and educators are reluctant about getting involved in advocacy (Gamson 1999; Milkoreit et al. 2015). However, Martin Luther King Jr. wrote, "freedom is never voluntarily given by the oppressor; it must be demanded by the oppressed" "Letter from Birmingham Jail" 1963). The environmental crisis is a problem of unequal distribution of resources due to the unequal distribution of power. Yet instead of challenging that power, we opt for non-confrontational approaches like changing diets and modes of transportation. And since environmental organizations are increasingly funded by private interests, challenging those interests can create considerable risk professionally.

Moreover, environmentalists are heirs to the legacy of the conservation movement, whose founders were a technocratic and elite group looking to preserve land for their own enjoyment (Taylor 2016). These people were not interested in challenging the capitalist system which had made them wealthy. Instead of mandating that industry clean up its pollution, pay a price on carbon emissions, or create products for reuse and longevity, industry allied environmentalists promoted the view that the captains of industry have no greater responsibility for the ecological crisis than individuals. Instead of making those who create the problem responsible, we blame their victims.

The third reason for timid environmentalism is that it continues to be influenced by neoliberal doctrines that gained widespread acceptance in the 1980s. Ronald Reagan and conservative thinkers of the era promoted the ideals of a limited government, a self-regulating free market that maximizes profits by consuming natural and human resources, and cutting social benefits for the middle and lower classes. Responsibility for environmental problems was reassigned from government and corporate entities to individual consumers and their decisions in the marketplace. In this context, environmentalism shifted its focus from regulating industry and penalizing wrongdoers to promoting "win-win" strategies that advertised green corporate consumerism while increasing corporate profits.

If individual actions are frequently inadequate and misguided, what can we do to create meaningful change? The problems such as climate change, loss of biodiversity, and sea level riseare urgent, and unless we can come together and implement systemic solutions, they will only become worse.

First, we need to realize that individual consumption is not the cause of the environmental crisis. Unless we live lavishly, our day-to-day energy consumption is insignificant in the overall scheme of things. Even if collectively we contribute to global warming, it is wrong to assume that it is all the result of our individual choices rather than the result of social, economic, and political forces that have, in large measure, made those choices for us.

Second, we need to take advantage of the fact that we are citizens in a participatory democracy first, and consumers second. As citizens, we have access to a wide array of tools for creating change besides consuming or not consuming. "Citizens can organize and mobilize, they can speak, publish, and change public opinion, they can lobby and introduce legislation, and they can vote and protest," says Derrick Jensen in "Forget Shorter Showers." If the institutions supposed to serve 
them do not, citizens have the right to change and abolish those institutions (Jensen 2009).

There are many groups today putting political advocacy in the service of climate action. 350 , in collaboration with indigenous and environmental justice groups, used protests, lobbying, and direct action to successfully oppose the Keystone XL pipeline, which would have transported crude oil from Canada's tar sands to the Gulf Coast (Borunda 2020). The fossil fuel divestment movement, started by students at Swarthmore College and championed by 350 , has caught fire around the globe and has led to institutional divestments of $\$ 14.48$ trillion (Fossil Free 2020). Another group, Citizens' Climate Lobby, is committed to federal carbon pricing legislation. The group has mobilized its supporters to lobby members of Congress to support the Energy Innovation and Carbon Dividend Act. To date, their efforts have resulted in co-sponsorship of the bill by 82 members of Congress and the introduction of 9 other carbon pricing bills into the 116th Congress (Citizens' Climate Lobby 2020; Resources for the Future 2020).

When asked "What is the most effective thing that someone can do to help reverse global warming?" Michael E. Mann, IPCC author and Distinguished Professor of Atmospheric Science at Penn State, responded, "Putting pressure on our elective representatives to act. We need to put a price on carbon and incentivize renewable energy to accelerate the transition underway from fossil fuels to green energy. But we cannot do that as individuals. Only our policymakers can do that. That means we must vote in politicians who favor action, vote out those who don't, and put as much pressure as possible (in the form of activism, letter-writing, organizing, you name it) on our policymakers to act now" (Hagan 2019).

I find hope in the young people today who are concerned about climate change and are aware that individual behavior is not enough to fight the climate crisis. Many of them, like Greta Thunberg, having given up flying and eating meat, still know that it is not enough. Last year, more than 7.6 million people around the world turned out to the youth climate strikes in September 2019 (350 2019). In addition, young people are writing letters to elected officials, attending lobby meetings and town halls, running for office, and organizing in their homes and on school campuses. They have created organizations that mobilize the young to act on climate change. Sunrise Movement, Zero Hour, Our Climate, and Fridays for the Future are all youth-led organizations founded since 2016 that work exclusively on climate change.

And their work is having an impact. Youth advocacy has made the Green New Deal the centerpiece of the Democrat Party platform in 2020 (Lavelle 2020). Youth climate lawsuits have been heard in local, state, and federal courts (Our Children's Trust 2020). Mass protests have catapulted the climate crisis from a fringe issue to mainstream public discourse. The youth climate movement, with its diverse participants, is making traditional environmentalists recognize that there is no climate justice without racial justice. They recognize that only the collective power of the people can bring about systemic change, and as adults, we should join them.

If 2020 has taught us anything, it is that collective crises need to be solved with collective action. Consider the global coronavirus pandemic. Countries that implemented statemandated lockdowns, testing, universal mask wearing, and other measures fared far better than countries that relied on voluntary measures. Similarly, voluntary individual behavior to reduce carbon footprints is no substitute for society-wide climate policy to keep warming below $1.5{ }^{\circ} \mathrm{C}$ by 2030 . Personal lifestyle changes like driving less and eating less meat are still important and stepping stones to bigger actions; however, they are insufficient. Science and advocacy are both needed to combat pandemics and the climate crisis.

\section{References}

350 (2019) 7.6 million people demand action after week of climate strikes. https://350.org/press-release/6-6-million-people-demandaction-after-week-of-climate-strikes/. Accessed 31 October 2020

American Public Transportation Association (2016) Public transportation benefits. http://www.apta.com/mediacenter/ptbenefits/Pages/ default.aspx. Accessed 29 December 2016

Borunda A (2020) Keystone XL stalls - again —along with other pipeline projects. National Geographic. https://www.nationalgeographic. com/science/2020/07/keystone-xl-stalls-again-along-with-otherpipelines/. Accessed 31 October 2020

Center for Responsive Politics (2020) 2020 election to cost $\$ 14$ billion, blowing away spending records. https://www.opensecrets.org/news/ 2020/10/cost-of-2020-election-14billion-update. Accessed 31 October 2020

Citizens' Climate Lobby (2020) Energy innovation and Carbon Dividend Act home. https://energyinnovationact.org/. Accessed 31 October 2020

Duke Today (2015) How much water does U.S. fracking really use? https://today.duke.edu/2015/09/frackfoot. Accessed 31 October 2020

Fat Knowledge (2006) CO2 emissions: light bulbs vs. cars. http:// fatknowledge.blogspot.com/2006/06/co2-emissions-light-bulbs-vscars.html. Accessed 31 October 2020

Fossil Free (2020) 1000+ divestment commitments. https://gofossilfree. org/divestment/commitments/. Accessed 31 October 2020

Frontier Group (2018) Trash in America: moving from a destructive consumption to a zero-waste system. https://frontiergroup.org/ reports/fg/trash-america. Accessed 31 October 2020

Gamson W (1999) Beyond the science-versus-advocacy distinction. Contemporary Sociology 28(1):23-26 http://www.jstor.org/stable/ 2653844. Accessed 31 Oct 2020

Hagan R (2019). Sixteen sustainability leaders weigh in: how YOU can help to reverse global warming. https://crowdsourcingsustainability. org/sustainability-leaders-how-you-can-help-stop-global-warming/. Accessed 31 October 2020

Jensen, D (2009) Forget taking shorter showers. Orion Magazine. https:// orionmagazine.org/article/forget-shorter-showers/. Accessed 31 October 2020

King Jr. M L (1963) Letter from Birmingham Jail. https://www.africa. upenn.edu/Articles_Gen/Letter_Birmingham.html. Accessed 31 October 2020 
Lavelle M (2020) Where is the Green New Deal headed in 2020? Inside Climate News. https://insideclimatenews.org/news/02012020/ green-new-deal-future-2020-election-climate-change-sandersocasio-cortez. Accessed 31 October 2020

Le Quéré C, Jackson RB, Jones MW et al (2020) Temporary reduction in daily global $\mathrm{CO} 2$ emissions during the COVID-19 forced confinement. Nat. Clim. Chang. 10:647-653. https://doi.org/10.1038/ s41558-020-0797-x

Magill B (2020) Water use rises as fracking expands. https://www. scientificamerican.com/article/water-use-rises-as-frackingexpands/\#: : text $=0$ i $1 \% 20$ and $\% 20$ natural $\% 20$ gas $\%$ 20 fracking, arid $\% 20$ states $\% 2 \mathrm{C} \% 20$ especially $\% 20$ during $\%$ 20drought. Accessed 31 October 2020

Milkoreit M, Moore ML, Schoon M, Meek CL (2015) Resilience scientists as change-makers - growing the middle ground between science and advocacy? Environmental science \& policy 53:87-95

Our Children's Trust (2020) Global legal actions. https://www. ourchildrenstrust.org/global-legal-actions. Accessed 31 October 2020

Resources for the Future (2020) Carbon pricing bill tracker. https://www. rff.org/publications/data-tools/carbon-pricing-bill-tracker/. Accessed 31 October 2020
Taylor D (2016) The rise of the American conservation movement: power, privilege, and environmental protection. Duke University Press

The Carbon Fund (2016) Reduce what you can, offset what you can't. https://www.carbonfund.org/reduce. Accessed 29 December 2016

U.S. Department of Agriculture, Economic Research Service (2020) Feed grains sector at a glance. https://www.ers.usda.gov/topics/crops/ corn-and-other-feedgrains/feedgrains-sector-at-a-glance/. Accessed 31 October 2020

U.S. Environmental Protection Agency (2020) Showerheads. https:// www.epa.gov/watersense/showerheads. Accessed 31 October 2020

U.S. Energy Information Administration (2019) U.S. energy facts explained. https://www.eia.gov/energyexplained/us-energy-facts/. Accessed 31 Oct 2020

U.S. Geological Survey (2016) Water use in the U.S., 2015 https://labs. waterdata.usgs.gov/visualizations/water-use-15/index.html\#view= USA\&category=publicsupply. Accessed 31 October 2020

United States Election Project (2020) Voter turnout data. http://www. electproject.org/home/voter-turnout/voter-turnout-data. Accessed 31 October 2020

World Meteorological Association (2020) United in science 2020. https:// public.wmo.int/en/resources/united in science. Accessed 31 October 2020 